\title{
Benign Thymoma
}

National Cancer Institute

\section{Source}

National Cancer Institute. Benign Thymoma. NCI Thesaurus. Code C66746.

A thymoma that is completely surrounded by a capsule, without evidence of capsular invasion, infiltration of the surrounding tissues, and metastases. 